\title{
AN X-RAY OF A GENOCIDE: PERSECUTION OF CATHOLIC CHURCH DURING THE SPANISH CIVIL WAR
} (1936-1939)

\author{
Pablo de la Fuente de Pablo \\ The John Paul II Catholic University of Lublin \\ Institute of History \\ Katolicki Uniwersytet Lubelski Jana Pawła II \\ Instytut Historii \\ pdelafuente@kul.lublin.pl
}

\begin{abstract}
One of the biggest genocides in the history of Spain has been the religious persecution during the Second Republic and the Spanish Civil War. Nowadays, the politically correct discourse tries to present those facts as a result of actions undertaken by uncontrolled people in a situation that was very difficult for the authorities to monitor. The truth is very different. Assassinations, tortures, rapes were committed in the majority of cases by militias formed and supervised by Republican authorities.
\end{abstract}

Keywords: Spain, 1936-1939, religious persecution, the Second Republic

A very important issue that needs to be tackled first is that the Spanish Civil War (1936-1939) was proclaimed by the Catholic Church as a Holy Crusade. The portrait of General Francisco Franco presented as a medieval warrior follows the principles of that kind of iconography (see: image 1). Franco is shown as a Christian defender of the Kingdom of Jerusalem. The symbolism is present not only in this picture. In fact it is quite widespread e.g. cardinal Enrique Pla y Deniel, the archbishop of Toledo - the Primatial See of Spain - wrote a pastoral letter entitled Dos ciudades ('The two cities') influenced by Saint Augustine's famous work The city of God. In his letter, the cardinal describes the Republican government as an allegory of a kind the earthly Jerusalem full of evil, whereas the rebels symbolise the celestial Jerusalem, the Kingdom of God. It is a kind of paradox that in the picture of Franco as a crusader, we can see a soldier of Regulares - the Muslim troops recruited in Northern Africa, which played an important role in the final victory. Nowadays, the figure of Franco who saved the Christian Spain, has been unfairly denigrated. 


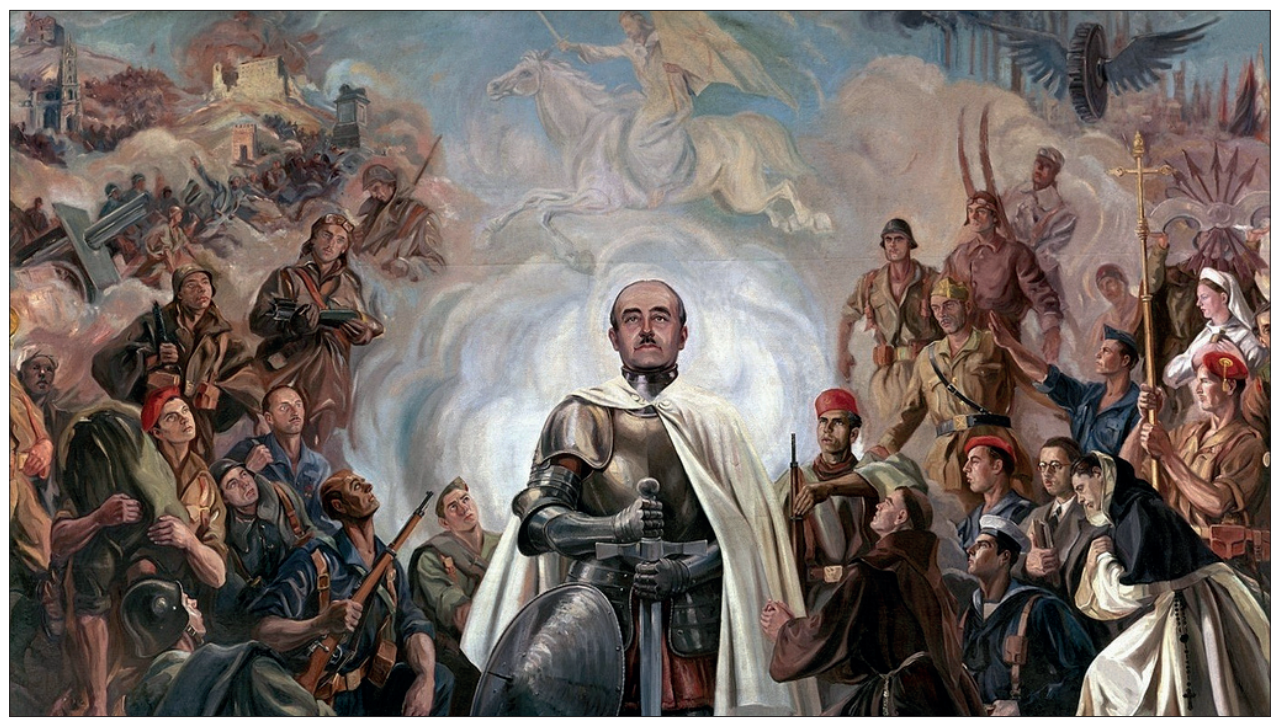

1. Arturo Reque Meruvia "Kemer", Allegory of Franco and the Crusade (1948-1949).

Source: Archivo General Militar de Ávila

Franco is the only military leader in history who won a crusade with an important number of Islamic soldiers fighting on his side.

What happened in the Catholic Church in 1936 to make it proclaim Franco's troops as a crusader army? The Church was not an active conspirator that provoked the uprising. The plot was developed by the conservative military men and a few businessmen. However, it must be kept in mind that the Church was indeed brutally repressed by Republican authorities. From 1931, when the Second Republic was vested with power, anticlerical actions became a common thing. However, the outbreak of the Civil War brought the persecution of Catholics to the level that was unheard of before.

\section{THE NUMBERS}

Montero affirms that 6,818 of the clergy and consecrated religious of the Catholic Church were assassinated i.e.: 12 bishops, 4,158 priests, 2,385 friars and monks, and 283 nuns $^{1}$. In total, more than $6 \%$ of the entire community. In order to put it into perspective and grasp the meaning of the facts, a comparison with the rev-

1 See: A. Montero, Historia de la persecución religiosa en España, Madrid 1961. See also: V. CÁrCEL ORTí, Caídos, víctimas y mártires. La Iglesia y la hecatombe de 1936, Madrid 2008. 
olutionary France can be made where only one French bishop was assassinated. In Republican Spain a dozen of Spanish bishops were martyred and the number would have been bigger if the Republican authorities had the opportunity to kill more.

\begin{tabular}{|c|c|}
\hline \multicolumn{2}{|c|}{ TOP 5 OF ASSASSINATIONS BY DIOCESES } \\
\hline Percentage of clergy and consecrated religious (\%) \\
\hline Barbastro & 87.8 \\
\hline Lérida & 65.8 \\
\hline Tortosa & 61.9 \\
\hline Segorbe & 55.4 \\
\hline Toledo & 47.6 \\
\hline Number of victims \\
\hline Madrid-Alcalá \\
\hline Valencia & 334 \\
\hline Tortosa & 327 \\
\hline Toledo & 316 \\
\hline Barcelona & 286 \\
\hline & 279 \\
\hline
\end{tabular}

The numbers multiply by three or four if we include the lay Catholics who were martyred at that time. It is difficult to provide the exact data due to the fact that there might have been other reasons for their execution. Although it goes without saying that a lot of ordinary churchgoers who were landowners, people exercising liberal professions and their families who were right-wingers - were killed solely because of their creed.

No wonder then that such a hecatomb brought the Church to the Francoist side. However, one of the key questions that need answering is what were the grapes of wrath that provoked this holocaust? Why did it happen in the home country of Saint Ignatius of Loyola, Saint Theresa of Jesus, and thousands of missionaries who spread the Catholic faith around the whole world? In my view in order to answer the question, two main elements need to be taken into consideration: one of them is a long-term factor, and the other is a short term one.

\section{THE ROOTS OF THE ANTICLERICALISM}

The long-term factor dates back to Napoleon's invasion of Spain in 1808 which not only resulted in decimating the Spanish civil population, but also sowed anticlericalism in a part of the Spanish elites. It is very important to underline that France has instilled this sentiment also in the current Europe basing it on anti-Christian foundations. It is not a coincidence that Valery Giscard d'Estaing, 
a Freemason and a former President of France, wrote the draft of the European Constitution which is a frontal attack on the Christian roots of the peoples of Europe $^{2}$.

The initial anticlericalism of the 19th century focussed mainly on religious orders and it gave rise to the desamortización i.e. disentailment - drastic reduction of the number of convents and monasteries, and the confiscation of their land and property. In other words, the biggest assault on private property in the name of the so-called liberal Spain. In this context the very word liberal is a contradiction in terms due to the fact that it refers to freedom and being free.

The short-term factor that led to the holocaust of Catholics during the Spanish Civil War can be traced back to the ideology of the Second Republic that came to life in 1931 after the collapse of monarchy in the aftermath of municipal elections. Although the supporters of monarchism scored higher than their opponents, the victory of Republican candidates in key cities such as Madrid and Barcelona brought the abdication of the king Alfonso XIII who interpreted the elections as referendum on monarchy vs republic.

Although the social profile of Spanish Catholic was mainly that of a monarchist conservative, the instauration of the Second Republic on April 14th, 1931, did not evoke any rejection among the churchgoing community. However, gradually, in view of the increasingly disturbing events, they started to reject the new regime with growing intensity. Many studies on religious persecution during the Spanish Civil War focus on crimes and statistics, omitting the roots of the hate that fed the genocide. How did it happen that such a big number of ordinary people became capable of committing such horrible crimes? Prevailing majority of the assassinations went far beyond simple life deprivation and involved acts of sadism with rapes, and brutal tortures. Furthermore, studies have revealed that the aggressors rarely showed any repentance for their inhumane behaviour. What ideological virus were their minds inoculated with? If they themselves perceived the atrocities they committed as something correct, it must have been because they were taught that they were doing the right thing.

The idea that the Catholic Church was an enemy of the Second Republic, and hence, in the view of the leftist ideologists, the enemy of the progress, was voiced on many occasions by the most prominent figures of the new regime ${ }^{3}$. It should be kept in mind that out of 470 Members of Parliament elected in 1931, 151 were Freemasons

2 J. CARO BAROJA, Introducción a una historia contemporánea del anticlericalismo español, Madrid 1980; J.A. Ferrer Benimeli, Masonería española contemporánea, Madrid 1980.

3 See: M. Martí Gilabert, Política religiosa durante la Segunda República Española, Pamplona 1998. 
belonging to several political formations ${ }^{4}$. One of the most representative parties inspired by the Freemasonry was Esquerra Republicana de Catalunya. It's by no means a coincidence that a Freemason symbol of the triangle is visible in the party's logo. This nationalist group led the regional government of Catalonia in 1936, and its Comitè Central de Milícies Antifeixistes (Central Committee of Anti-fascist Militias), and was directly responsible for the holocaust of more than 8,000 Catholics. Freemasons were not concentrated in one political group, but infiltrating all formations and structures of power. Almost all parties represented in the parliament had Freemasons among their members. Freemasonry ideology fed the anti-Catholic hate and loggias provided dialectical strategies to their members. Burning the victims alive was a frequent way for the assassins to precede, but the moral matchthat lit this fire was provided by this secret society.

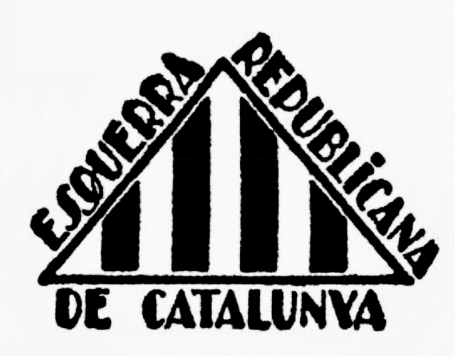

2. The party logo of the Esquerra Republicana de Catalunia referring to Freemason symbolism. Source: "Escuerra Republicana [online, accessed: 17 VI 2019], available at: <www.esquerra.cat>

\section{FROM ANTICLERICALISM TO HOLOCAUST}

Evidently, instigating anti-Catholic sentiments that culminated in the martyrdom of thousands of Christians was a long-term process. It led not only to numerous assassinations but also prolonged macabre ceremonies that preceded the killing. A common procedure was the castration of priest and putting the amputated genitals inside the victim's mouth ${ }^{5}$. There was no mercy or pity for the victim, and the perpetrators clearly demonstrated that they were convinced of having done the right thing and followed their ethics. It should be born in mind that both clergy and

\footnotetext{
4 J. Albertí, La Iglesia en llamas. La persecución religiosa en España durante la guerra civil, Barcelona 2008, p. 109-110.

5 P. De la Fuente de Pablo, La carretera del Gólgota: el martirio de sacerdotes en Rosas (Gerona) durante la Guerra Civil Española, "Roczniki Humanistyczne”, 65/2(2017), p. 140-141.
} 
members of religious communities wear characteristic clothes. In Spain - a country with long Catholic tradition, the special attire evoked strong connotations with dignity and respect. Defying the connotations and conducting the inhumane attacks was the result of the social engineering shaped by a fine ideological rain.

Some authors have explained that religious communities of monks, friars and nuns were the problem which gave rise to the anti-clericalism in Spain. They seem to find the proof of that claim in the fact that the first attacks against the Church were aimed at religious orders. They took place in 1931, five years before the outbreak of the Civil War. Several monasteries and convents were assaulted and destroyed by lefty bands. It has to be underlined that the authorities were clearly aware of the crimes that were committed. "No convent is not worth the life of a Republican" - said Manuel Azaña, the Republican Prime Minister ${ }^{6}$. In line with these words, the rioters were not criminals but Republicans - i.e. defenders of the new political regime. Such approach was especially painful because the minister of Home Affairs of the Republican government was Miguel Maura, who was a Republican but also a confessed Catholic. However, he was not as important as Azaña, a Freemason, who bypassed Maura and gave direct orders that permitted the bands to do as they pleased.

Another element that needs taking into consideration is the fact that in the view of some historians the Spanish Catholic Church was an antidemocratic institution ruled by fundamentalists who disobeyed the Vatican's instructions to remain indifferent to the political system of the country and to respect its legal authorities ${ }^{7}$. The proof of the fundamentalism was the standpoint of cardinal Segura who expressed his support of monarchy and as a result was expulsed from Spain in 1931. All attempts at mitigating the tension made the same year by the Holy See's Secretary of State, cardinal Pacelli ended up in a fiasco. In order to achieve their goal, Republican authorities used the concordat of 1851 to force the Vatican to substitute the archbishop of Toledo. The agreements between Spain and the Holy See lost their legal grounds because according to the constitution of the new republic Spain lost the status of a confessional country which was reflected in the concordat ${ }^{8}$.

Yet another proof that the new republic aimed at downgrading Catholics and treating them as second category citizens is the story of the Jesuits. The new constitution, adopted in 1931, in its article 27 in a veiled way banned the Jesuits who were the intellectual vanguard of the Church from Spain:

\footnotetext{
6 J. Albertí, La Iglesia..., p. 96.

7 H. Raguer, La pólvora y el incienso, Barcelona 2001, p. 40.

8 J.M. Bueno Monreal, Las relaciones entre la Iglesia y el Estado en los modernos concordatos, Madrid 1931.
} 
All the religious orders whose rules in addition to the three canonical vows impose another one with special obedience to another authority different that the one legitimised by the State shall be disbanded.

The Jesuits professed the fourth vow of absolute obedience to the Pope. On the surface this constitutional article referred to the legal problem of a situation in which a Spanish citizen could obey a chief of a foreign State - in this case the Holy See. However, no such measures were taken against the communists, although the party members blindly followed the orders that came from Joseph Stalin.

The next element of the pre-war persecution - was the Confessions and religious congregations act (1933). It followed the anticlerical ideology and established a new law according to which educational institutions run by the Catholic Church had to be dismantled. What's more the law went even further that and allowed for expropriating the Church and confiscating its real estate including temples, convents, monasteries etc., which from then on were considered the property of the State. The religious persecution did not stop there and it reached the level that no democratic state has seen before. Not only were Christian symbols demolished at cemeteries, it was prohibited to display any Christian symbol during funeral processions too. Even ringing the church bells for any purpose at all including to mark the time was banned.

All the measures implemented to fight Catholics built distance between them and the Second Republic. The anticlerical obsession of the Republican authorities went as far as forbidding cheering Viva Cristo Rey! in public ${ }^{9}$. Proclaiming Jesus Christ as a king is something common in the Holy Bible, but it got a new significance in the political system where Catholics were perceived to be lesser citizens. The Bishop of Barcelona, Manuel Irurita claimed that Jesus was the monarch that Republicans could never remove ${ }^{10}$. In this context it is understandable why the above-mentioned pastoral letter of cardinal Pla y Deniel inspired by Saint Augustine of Hippona said: the city of God as a kingdom of the goodness that stands in opposition to the Second Republic perceived to be the city of the evil. The confrontation of monarchy vs Republic is evident. The kingdom of God was far superior to the Republic of the wicked.

Apart from the fact that the Second Republic was a regime strongly marked by Freemasons, the country was plagued by yet another important process i.e. the bolshevisation of the Socialist Party which in 1933 was the main left-wing party. For the

\footnotetext{
9 J.F. Guijarro, Persecución religiosa y guerra civil. La iglesia en Madrid, 1036-1939, Madrid 2006, p. 74 .

${ }^{10}$ J. Albertí, La Iglesia..., p. 91.
} 
socialist leader, Francisco Largo Caballero, called the Spanish Lenin, the Second Republic was merely an intermediary stage, a step on the way to the communist revolution. Such an atmosphere explains why the revolutionaries concentrated their hate on the Catholic Church as the main symbol of the old regime. To them the destruction of Catholics and Church property was a symbol of social change. Antoine de Saint-Exupéry, the renown author of The Little Prince, and newspaper correspondent in Spain wrote: "here, murders are as common as tree felling"" .

Another important aspect to take into consideration is that although the assassinations of Catholics peaked during the Civil War, they had some serious precedents during the riots of Asturias in October, $1934^{12}$. After the lefty coalition lost the power in national elections one year earlier, two rebellions against the right-centre government broke out. One of them was the nationalist revolt in Barcelona, and the other one was in the above-mentioned mining region of Spain where 34 religious were brutally murdered.

One of the myths widespread by left wing historians is that the Catholic holocaust, especially in the summer of 1936, was the result of actions undertaken by groups of the so called incontrolados people who were under no control. The studies I have conducted as an expert of the Historical Commission on the Beatification and Canonisation of God's Servant Martyr Pere Arolas and Companions set up by the bishop of Gerona several years ago proved that religious persecution was daily practice of Republican authorities. In the case of Catalonia, where the number of crimes was substantial - one in four assassinations of religious people was conducted in this infamous region of Spain - the incontrolados were members of the Comitè Central de Milícies Antifeixistes, an agency founded by Lluís Companys, president of the Generalitat (or regional government) of Catalonia ${ }^{13}$.

When a part of the Spanish Army rose up in July, 1936, the Church was not a part of the plot, however, as a consequence of the persecution it had suffered, the war against the Republicans was officially declared a crusade ${ }^{14}$.

In order to support the false notion of the "uncontrolled" killings, an argument is used saying that the most part of the assassinations took place in 1936 during the first six months of the Civil War. Theoretically, the Republican authorities were overwhelmed by the events and could not control the situation. However, the claim does not hold water especially with regard to priests and members of religious orders. In that period the number of assassinations perpetrated by Republicans did

${ }^{11}$ C. García Santa Cecilia, Corresponsales en la Guerra de España, Madrid 2007, p. 56.

${ }^{12}$ A. Garralda, La persecución religiosa del clero en Asturias, Avilés 1977.

${ }^{13}$ P. De la Fuente de Pablo, La carretera...

${ }^{14}$ H. Raguer, La pólvora..., p. 86. 
not increase because they were no longer able to capture them so easily. In the case of Catalonia, where the genocide was especially horrid, the survivors of the holocaust escaped through the French border. In the case of Madrid, where fleeing out of Spain was really difficult, thousands of people took refuge in diplomatic legations. The horrible repressions decreased mainly because the volume of hunting pieces was reduced.

\section{AFTERMATH}

In the face of rising opposition Republican authorities instead of building a democratic state gave free rein to social engineering projects. The art. 27 of the Constitution of 1931 on religious liberty became a scrap paper. No constitutional guarantee was respected by the authorities. Arrests, tortures, rapes, illegal trials of lay churchgoers and religious became commonplace.

As an epilogue only a short remark on the prosecution of the 1931-1939 crimes during the Franco's regime. Firstly, one of the saddest things of the former Prime Minister José Luis Zapatero's legacy is the Historical memory act (2007). Its article 2.1 declares the "radical injustice of all the judgements... during the Civil War". I cannot believe that the sentence of a tribunal that condemned the cruel rapist and murderer of a nun can be considered unjust. My rather detailed research of only 50 assassinations of priests clearly shows that few of the murderers were arrested and even fewer of them were executed. Majority of the perpetrators escaped the justice. Attempts at catching the criminals and putting them before court were rather weak and they were carried out in the years that immediately followed the War. In 1969, to commemorate the thirty years that have passed from the end of the War, general Franco introduced an end-point act. The law stood in opposition to the practices of the communist regimes in Eastern Europe where the party members losing power introduced laws that assured their own immunity after the change of the system. The spirit of the Francoist law on amnesty did not assure immunity of the Francoist watching the end of the regime but the pardon of its enemies. In fact, during the 1960 's, a few years before the act, the authorities turned a blind eye and some criminals came back from the exile. 


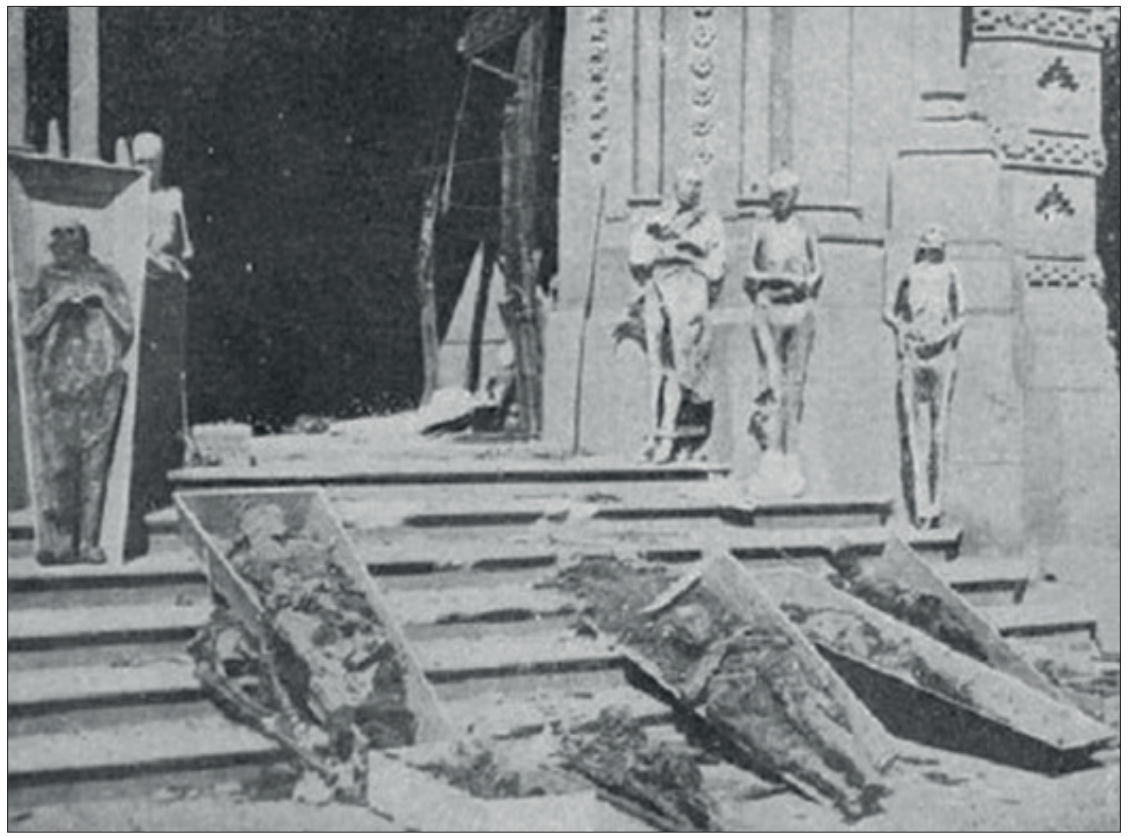

3. Profanation of sepulchres in the Church of Las Salesas.

Source: Causa General. La dominación roja en España. Avance de la información instruida por el ministerio público. Prólogo del Excmo. Sr. Ministro de Justicia, Madrid [1943?]

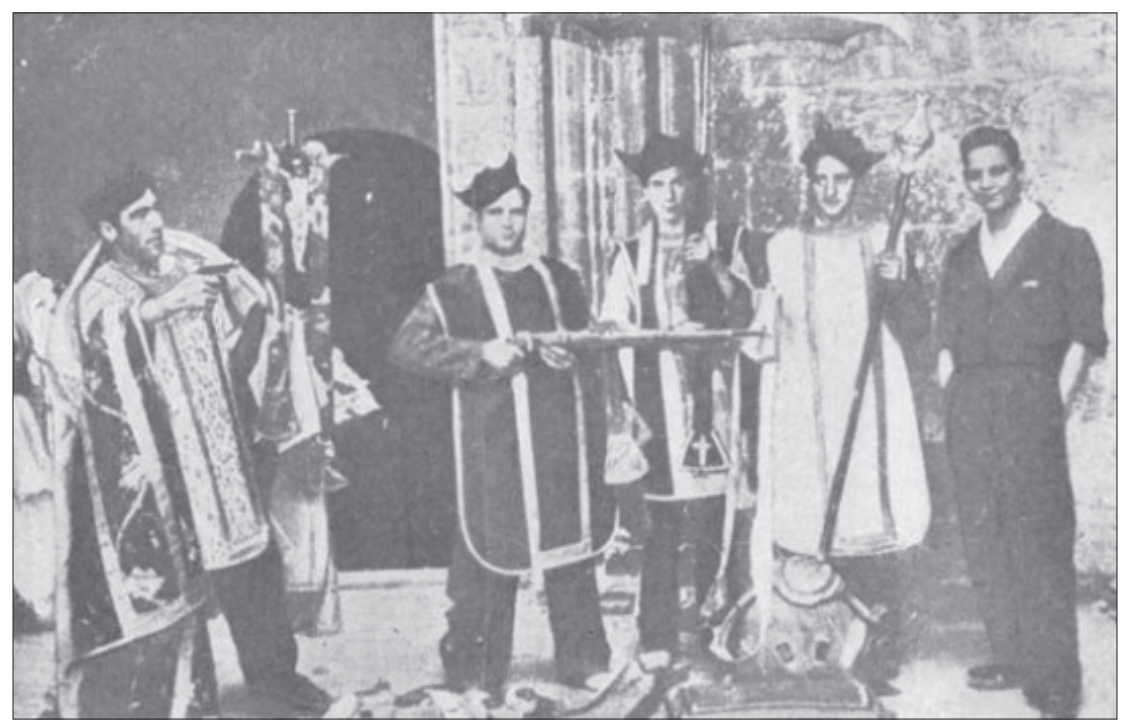

4. Church profanation - perpetrators in mock disguise of clergy clothing.

Source: Causa General. La dominación roja en España. Avance de la información instruida por el ministerio público. Prólogo del Excmo. Sr. Ministro de Justicia, Madrid [1943?] 


\section{BIBLIOGRAPHY}

AlberTí J., La Iglesia en llamas. La persecución religiosa en España durante la guerra civil, Barcelona 2008.

Bueno Monreal J.M., Las relaciones entre la Iglesia y el Estado en los modernos concordatos, Madrid 1931.

CÁrcel Ortí V., Caidos, víctimas y mártires. La Iglesia y la hecatombe de 1936, Madrid 2008.

CARo BAROJA J., Introducción a una historia contemporánea del anticlericalismo español, Madrid 1980.

Causa General. La dominación roja en España. Avance de la información instruida por el ministerio público. Prólogo del Excmo. Sr. Ministro de Justicia, Madrid [1943?].

Ferrer Benimeli J.A., Masonería española contemporánea, Madrid 1980.

Fuente de Pablo P. De LA, La carretera del Gólgota: el martirio de sacerdotes en Rosas (Gerona) durante la Guerra Civil Española, "Roczniki Humanistyczne", 65/2(2017).

García Santa Cecilia C., Corresponsales en la Guerra de España, Madrid 2007.

GaRRalda A., La persecución religiosa del clero en Asturias, Avilés 1977.

GuiJarro J.F., Persecución religiosa y guerra civil. La iglesia en Madrid, 1036-1939, Madrid 2006.

Martí Gilabert M., Política religiosa durante la Segunda República Española, Pamplona 1998.

Montero A., Historia de la persecución religiosa en España, Madrid 1961.

RAGUER H., La pólvora y el incienso, Barcelona 2001.

\section{RADIOGRAM LUDOBÓJSTWA: \\ PRZEŚLADOWANIA KOŚCIOŁA W CZASIE WOJNY DOMOWEJ W HISZPANII}

(1936-1939)

Streszczenie. Jednym z największych ludobójstw w historii Hiszpanii były mordy, do których doszło w wyniku prześladowań religijnych z okresu Drugiej Republiki oraz hiszpańskiej wojny domowej. Obecnie w ramach politycznie poprawnego dyskursu usiłuje się przedstawiać te fakty jako działania podejmowane przez osoby niekontrolowane przez ówczesne władze w trudnej do monitorowania sytuacji. Prawda jest jednak zupełnie inna. Zabójstwa, tortury i gwałty popełniały w przytłaczającej większości oddziały milicji, stworzone i nadzorowane przez władze Republiki.

Słowa kluczowe: Hiszpania, 1936-1939, prześladowania religijne, Druga Republika. 